\title{
Reducing Emissions from Deforestation and Forest Degradation (REDD) in Nepal: A Review
}

\author{
Bunu Gauli ${ }^{1}$ and Suraj Upadhyay ${ }^{2}$ \\ Corresponding author: Bunu Gauli \\ Email: bunugauli@gmail.com
}

\begin{abstract}
Reducing Emissions from Deforestation and Forest Degradation (REDD) in developing countries is a mechanism that allows industrialized countries to offset their emissions by purchasing carbon credits from developing countries, which reduce emissions from deforestation and forest degradation by avoiding such activities. The Government of Nepal is committed to REDD through reversing deforestation and forest degradation, conservation of existing forest and enhancing forest carbon stocks, while addressing livelihoods concerns at the same time since 2009 and now it has been flourished in the country along with concept of sustainable development of the forest resource of country. Nepal has undergone different stages during this process and has planned certain strategy for the future. The assemblages of the available information on REDD in Nepal is important to over view its holistic prospect, aspect and potentiality in the least developing country like Nepal which holds the greater possibility to be benefited from the REDD. Nepal is now in the process to prepare national REDD strategy by 2013 and there are different On Going REDD -Plus Piloting Initiatives in Nepal. Nepal has greater potentiality of being benefited from REDD though some policy related to it needed to be redefined and clarify.
\end{abstract}

Key Words: REDD, Livelihood, Strategy, Benefits, Initiatives

\section{Background}

Climate change is the direct result of an increased atmospheric concentration of greenhouse gases (GHGs). These GHGs are emitted from a wide variety of sources like fossil fuel based transportation, industrial complexes, agricultural land, and deforested and degraded land. Deforestation and forest degradation have been estimated to account for up to $20 \%$ of total annual GHG emissions (IPCC, 2007). Changes in forest cover and carbon stocks have been particularly prominent in developing countries, and especially in the least developed

Environmental Science, TU

Nepal Program Coordinator, Seed Tree (www.seedtree.org) 
countries (LDCs). As these countries continue to grow, their deforestation and degradation rates have only increased. If these rates are not checked, the contribution of deforestation and forest degradation to GHG emissions will continue to rise and will have far reaching consequences for livelihoods and ecosystem services in general (Stern, 2007).

REDD is primarily about reducing atmospheric carbon dioxide emissions as an element of a comprehensive approach mandated by the Bali Action Plan. The Bali Action Plan, a decision adopted at the Conference of Party meeting in Bali, Indonesia in December 2007 (COP 13), explicitly mentions the need to address REDD to mitigate GHGs (Acharya, et al., 2009). The basic idea behind Reducing Emissions from Deforestation and Degradation (REDD) is simple: countries that are willing and able to reduce emissions from deforestation should be financially compensated for doing so. Previous approaches to curb global deforestation have so far been unsuccessful, however, and REDD provides a new framework to allow deforesting countries to break this historical trend (Parker, 2009).

Reducing Emissions from Deforestation and Forest Degradation (REDD) is an incentive based mechanism which is being discussed under the aegis of the United Nations Framework Convention on Climate Change (UNFCCC) in an effort to reduce concentration of carbon dioxide in the atmosphere. In recent UNFCCC discussions, REDD has been expanded to REDD+ with the inclusion of a wider range of forest-related activities/services to previously proposed, which allows REDD+ to recognize the roles of participatory forest management regimes in promoting sustainable forest management (e.g. community forestry, joint forest management, collaborative forest management) - enabling local communities to access financial mechanisms provided by climate regime, at least in the theory (Karky, et al., 2011).

Reducing Emissions from Deforestation and Forest Degradation (REDD) in developing countries is a mechanism that allows industrialized countries to offset their emissions by purchasing carbon credits from developing countries, which reduce emissions from deforestation and forest degradation by avoiding such activities. In fact, REDD is a win-win strategy whereby host countries can be compensated for their land use, while industrialized countries are expected to pay less than half of the prices of other types of carbon credits (Dhital, 2009).

In Nepal, forests are considered the second most important natural resource after water. Forests serve three important functions: production of timber and Non-timber Forest Products (NTFPs), protection of natural environment and regulation of atmospheric condition. In the Nepalese context, the production function of the forest enhances economic benefits for the community, while the protection and regulation functions are for ecological betterment and climate regulation respectively. The forest area of Nepal is estimated to be about 5.8 million hectares (ha) (40\% of the total geographical area of the country), out of which 4.2 million ha (29\%) is forest and 1.6 million ha (10.6\%) is shrub land (DFRS, 1999). The overall deforestation rate of Nepal is currently $1.7 \%$, which is well above the Asian average (1\%) and the global average (1.3\%) (MFSC, 2008). 
Globally, deforestation results in the annual loss of 13 million ha of forests (FAO, 2005). A comparison of the results of the National Forest Inventory (NFI) with those of the Land Resources Mapping Project (LRMP) shows that the forest area in the country decreased by $24 \%$ at an annual rate of $1.6 \%$ over a period of 15 years (1979-94) and the shrub land area increased by $126 \%$ during the same period (MFSC, 2008). Higher increase in the proportion of shrub land contiguous with continuing decrease in overall forest area gives a clear picture of the state of deforestation and forest degradation in Nepal.

Deforestation contributes to global climate change. It is considered to be the cause of about $20 \%$ total Greenhouse Gas (GHG) emissions. To avoid the worst impact of human-induced climate change, average global surface temperature rise needs to be stabilized as far as possible below $2^{0} \mathrm{C}$ above the pre-industrial level (IPCC, 2007). Limiting warming to this level is likely to be critical to the protection of forests, which are considered the major natural sink for GHGs. Reducing emission from deforestation is the key to achieving such goal.

In the past, governments relied on regulatory instruments to reduce deforestation and environmental degradation of the mountain forests, but these mechanisms have proven inadequate. Nepal, for example, has one of the highest deforestation rates among nontropical countries (FAO, 2003).

\section{Importance of REDD in Nepal}

The area of the country is 14.78 million ha, of which forest covers about 5.8 million ha i.e. $39.6 \%$ of this. With population growth and forest product and land demands, deforestation and degradation of the forest could be aggravated in the years to come, affecting the livelihoods of a large number of forest-dependent people and Nepal's environmental sustainability. The Government of Nepal is committed to REDD through reversing deforestation and forest degradation, conservation of existing forest and enhancing forest carbon stocks, while addressing livelihoods concerns at the same time. (MFSC, 2010). REDD concept has been introduced in Nepal since 2008 and now it has been flourished in the country along with concept of sustainable development of the forest resource of country. Nepal has undergone different stages during this process and has planned certain strategy for the future. This review work summarizes all these steps of sprouting and development of REDD in Nepal along with the future prospective of it in present scenario. 
History on establishment of REDD:

\begin{tabular}{l}
\hline In the 1997 the K yoto Protocol, excluded forest \\
\begin{tabular}{|c|}
\hline Deforestation increased, formation of the Coalition of Rainforest \\
Nations
\end{tabular} \\
\hline In 2005at COP11 in M ontreal, an idea called REDD was introduced \\
\hline In 2007at COP13 in Bali, REDD had morphed into REDD+ \\
\hline \\
\hline \\
In 2009 at COP15 in Copenhagen agreement on the specifics of an \\
international REDD (+) mechanism was set
\end{tabular}

\section{Establishment of REDD}

- Reducing Emissions from Deforestation and Forest Degradation (REDD)

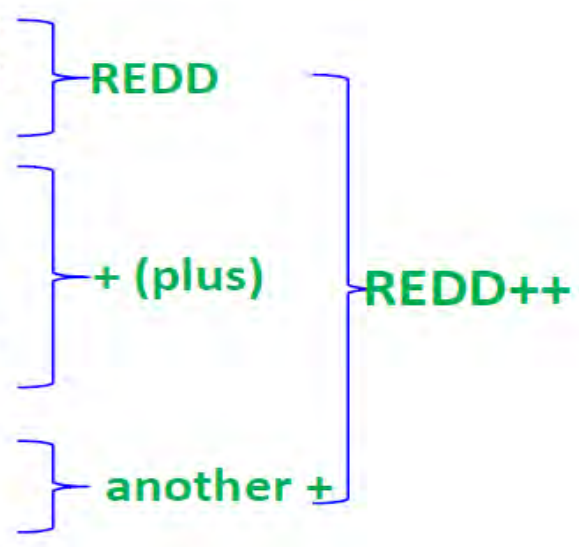

\section{REDD in Nepal}

REDD concept was introduced in Nepal in 2008 and declared as a Ministerial priority by the ministry of Forests and Soil Conservation as REDD Forestry and Climate Change Cell. World Bank has established the Forest Carbon Partnership Facility (FCPF) to assist selected developing countries in their efforts to reduce their emissions from deforestation and forest degradation primarily through capacity building and institutionalizing a performance based 


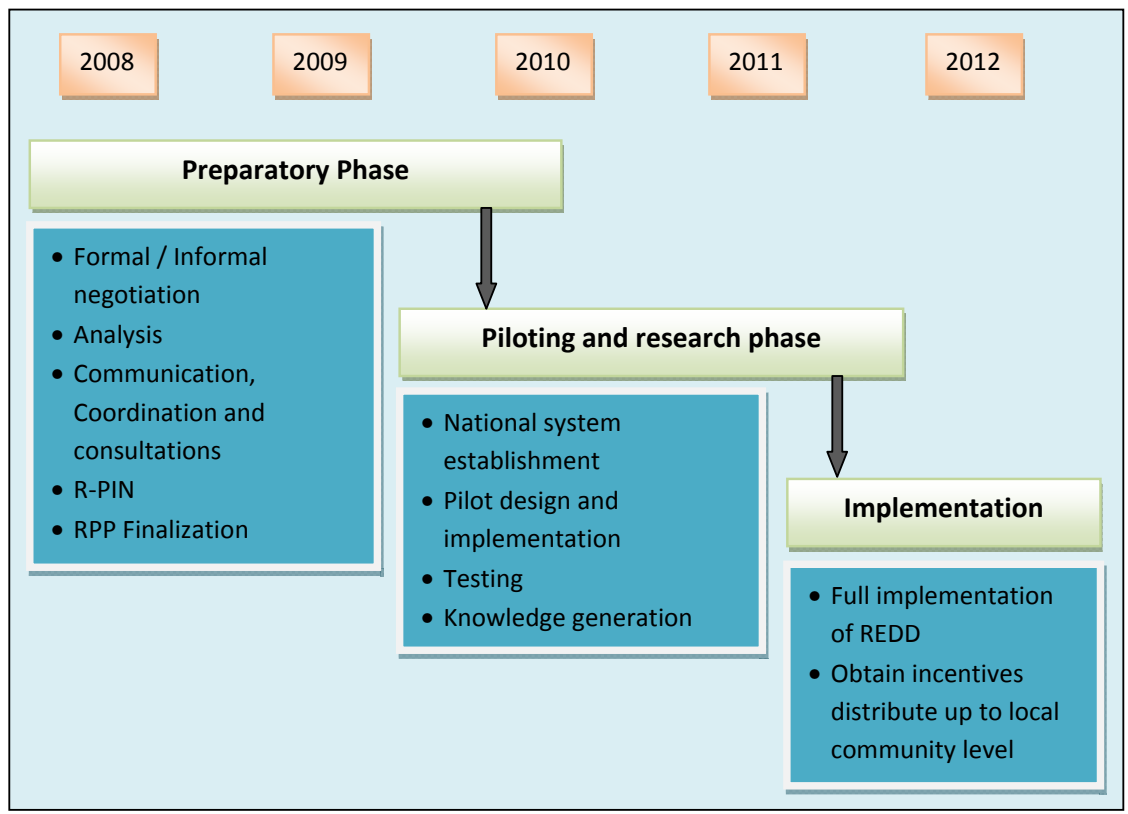

incentive mechanism. FCPF is a global partnership of 37 forested developing countries, 14 donor countries and organizations, and civil society, indigenous peoples, private sector, and international organization observers. FCPF is working to pilot REDD-plus. Among many Nepal is one of the countries selected by the FCPF for the REDD readiness. Nepal is now in the process to prepare national REDD strategy by 2013.

Aiming to design and setting up a governance and payment system for Nepal's community forest management under REDD+, International Centre for Integrated Mountain Development

Roadmap of REDD strategy options of Nepal (PSPL\& FECOFUN, 2010)

It should be revised because Nepal has been working in REDD+.

\section{REDD in Present Status}

(ICIMOD) is working on piloting REDD+ in three watersheds (Charanawati in Dolakha, Kayarkhola in Chitwan and Ludikhola in Gorkha) of Nepal covering three geographic regions the High Mountain, the Mid-hills and the Terai.

Estimates of the potential global value of REDD+ payments depend mainly on the underlying assumptions. Assuming a conservative carbon value of \$10 per ton of carbon dioxide (CO2), estimates include a net present value of $\$ 150$ billion (Chomitz et al., 2007 cited in Acharya et al., 2009) and annual revenue of \$2.3-12 billion (Ebeling, 2006; El 
Lakany et al., 2007 cited in Acharya et al., 2009). But with more positive assumptions about the carbon price (\$10-20/t CO2e) and deforestation reduction rates (20- 50 per cent), estimates for annual REDD revenues are at \$7-23 billion (El Lakany et al., 2007 cited in Acharya et al., 2009). Hence the REDD+ program could be a significant source of sustainable finance.

\section{On Going REDD -Plus Piloting Initiatives in Nepal}

\begin{tabular}{|c|c|c|c|c|c|}
\hline REDD Initiative & $\begin{array}{c}\text { Supporting } \\
\text { Organization }\end{array}$ & Purpose & $\begin{array}{l}\text { Physiographic } \\
\text { region }\end{array}$ & $\begin{array}{c}\text { Forest } \\
\text { Management } \\
\text { Regime } \\
\end{array}$ & $\begin{array}{l}\text { Current } \\
\text { Status }\end{array}$ \\
\hline $\begin{array}{l}\text { REDD plus } \\
\text { piloting }\end{array}$ & $\begin{array}{l}\text { Norway } \\
\text { (ICIMOD/ } \\
\text { ANSAB/ } \\
\text { FECOFUN) }\end{array}$ & $\begin{array}{l}\text { Set up and pilot } \\
\text { REDD Payment and } \\
\text { benefit sharing \& } \\
\text { Capacity building } \\
\end{array}$ & $\begin{array}{l}\text { Mid-Hills (3 } \\
\text { Watersheds) }\end{array}$ & $\mathrm{CF}$ & $\begin{array}{l}\text { On } \\
\text { going till } \\
2013\end{array}$ \\
\hline $\begin{array}{l}\text { Grassroots } \\
\text { Capacity } \\
\text { Building in } \\
\text { REDD+ } \\
\end{array}$ & $\begin{array}{l}\text { Norway } \\
\text { (RECOFTC } \\
\text { and } \\
\text { FECOFUN) }\end{array}$ & Awareness/ Training & $\begin{array}{l}\text { Terai and Mid- } \\
\text { hills } \\
\text { (16 Districts) }\end{array}$ & $\mathrm{CF}$ & \\
\hline $\begin{array}{l}\text { Reducing } \\
\text { Poverty } \\
\text { through REDD: } \\
\text { early action }\end{array}$ & $\begin{array}{l}\text { WWF/ } \\
\text { WINROCK } \\
\text { international }\end{array}$ & REDD plus Piloting & $\begin{array}{l}\text { Terai and } \\
\text { inner Terai (14 } \\
\text { Districts) }\end{array}$ & $\begin{array}{l}\text { CF/BZ/ } \\
\text { SMF }\end{array}$ & Ongoing \\
\hline $\begin{array}{l}\text { Climate Change } \\
\text { and REDD }\end{array}$ & DFID (LFP) & Awareness & $\begin{array}{l}\text { Mid-Hill (12 } \\
\text { Districts) } \\
\text { Terai (3 } \\
\text { Districts) } \\
\end{array}$ & $\mathrm{CF}$ & $\begin{array}{l}\text { Baseline } \\
\text { on } \\
\text { Carbon } \\
\text { stock } \\
\end{array}$ \\
\hline $\begin{array}{l}\text { Climate Change } \\
\text { and REDD }\end{array}$ & $\begin{array}{l}\text { SDC } \\
(\mathrm{NSCFP})\end{array}$ & $\begin{array}{l}\text { CC literacy for } \\
\text { piloting }\end{array}$ & $\begin{array}{l}\text { Mid-hills } \\
\text { (4 Districts) }\end{array}$ & $\mathrm{CF}$ & Ongoing \\
\hline
\end{tabular}

(Poudel. K.C., \& Dangi.R., 2011)

\section{Benefits from REDD}

REDD+ has been embraced by environmentalists, not only because of its potential to reduce deforestation in the tropics but also because of its strong biodiversity co benefits like:

- Climate benefits: As natural sinks, forests reduce up to $20 \%$ of global emissions; they strengthen adaptive capacity of the ecosystems and aids adaptation.

- Biodiversity benefits: Could prevent the loss of habitat and strengthen biodiversity conservation outcomes.

- $\quad$ Social benefits: Can support traditional livelihoods and cultural values associated with forests; and build capacity for sustainable forest management.

- $\quad$ Livelihood benefits: Carbon revenues can substantially reduce the poverty incidence; Complementary activities like NTFP collection, sustainable timber harvesting, and eco-tourism could be carried out. 
- Miscellaneous ecosystem services benefits: Rainfall regulation, water quality and regulation, soil conservation, reduced disease risk, reduced fire risk, maintenance of pollinator populations (Acharya et al., 2009)

Nepal is often touted as an international example of successful community-based forest management, especially in the Middle Hills region where deforestation has been steadily reduced over the past couple of decades. In many instances, the condition of these forests is being continually enhanced, thus contributing to a steady increase in carbon stocks. As a result, Nepal has lobbied for the inclusion of "forest enhancement" (i.e., REDD+) to make it more competitive in a global carbon-trading scheme. In the international arena, the meaning of "REDD+" is often expanded to include both forest enhancement and social and biodiversity co-benefits, in addition to avoiding deforestation and forest degradation. REDD+is a relatively new proposal advanced by some countries, with no clear international consensus yet on its viability or desirability. It would incorporate all emissions from different land uses and land use change, including afforestation, grasslands and agricultural lands. It is unclear yet whether REDD+ would work to Nepal's advantage. However, the complexity of measuring, monitoring and recording carbon emissions and/or stocks in other types of land use would certainly pose additional technical and institutional challenges and increase transaction costs.

In Nepal, the government, donor agencies and some civil society organizations have embraced the promise of REDD, fast-tracking national policy development and instigating various piloting and awareness-raising activities in order to get "ready for REDD". They recognize that this emerging mechanism presents an opportunity for Nepal and its forestdependent communities to reap significant benefits and to play an active role in climate change mitigation. In fact, REDD could acknowledge the important role that forests and the communities that protect them already play through carbon sequestration; and also provide incentives for both governments and local stakeholders to bolster their forest conservation efforts.

Funding forest management to avoid deforestation, forest degradation, conservation of forest carbon and enhancement of forest carbon under REDD+ plus could be an effective policy mechanism for reducing emissions and carbon sequestration. However, to work such a mechanism for the benefit of both the buyer from the industrialized world and the seller from the community groups from developing countries is a challenging task. Therefore, it is important to devise a policy mechanism that safeguards local community rights and interests. The entire pilot projects trying to addresses the current issues surrounding REDD+ policy from a community perspective (MFSC, 2011).

The CFM sector has contributed to the sustainable management of forests in about 1.1 million ha or around $25 \%$ of the total national forest area. Without the CFM policy, deforestation and degradation probably would have been much higher. So CFM policy could be the entry point for REDD, contributing to the expansion of sustainable forest management 
practices in areas with high deforestation and degradation rates. The REDD scheme is also a great opportunity for raising the awareness of indigenous peoples on sustainable resource management. At the same time, this is also an opportunity for indigenous people to share their traditional knowledge of sustainable forest management so that it can be applied to a broader setting.

\section{Conclusions}

This paper is prepared with the objective to document the REDD activities in Nepal from the initial stage to date and assemblage the information available. The assemblages of the available information on REDD in Nepal is important to over view its holistic prospect, aspect and potentiality in the least developing country like Nepal which holds the greater possibility to be benefited from the REDD.

REDD + can play a strong role in not just mitigation, but also in adaptation, by increasing the resilience of ecosystems. As REDD+ is a new concept whose architecture is still being developed, new policies need to be introduced while old ones must be updated and brought in line with the new mechanism. The government can play a major role in guiding the implementation and operation of a REDD+ mechanism. An effective, efficient and transparent governance structure should be created to ensure maximum benefits. As Nepal is in the initial stage of developing its capacity in REDD+ process, a roster of experts and local resource persons have to be maintained at REDD Cell. These people can be used in future capacity building, outreach and consultation process. All the projects have strong contribution in national REDD+ process. Several data have been generated, human resources have been developed, tools/guidebooks/methodologies also have been developed from field work. It is also necessary to link these achievements up to meso and macro level for which mechanisms should be developed to manage and utilize all these achievements of the pilot projects.

Also, before recommending international carbon-trading schemes such as REDD for Nepal we must study and draw lessons from the outcomes of existing Payment Ecosystem Service schemes; conceptualize carbon as but one element in a suite of nested environmental services provided by forests; innovate a variety of carbon trading options; and resolve fundamental constraints to effective forest governance.

\section{References}

Acharya, K.P., Dangi, R.B., Tripathi, D.M., Bushley, B.R., Bhandary, R.R. and Bhattarai, B. (eds.). 2009. Ready for REDD? Taking Stock of Experience, Opportunities and Challenges in Nepal.: Nepal Foresters’ Association: Kathmandu, Nepal.

Dhital. 2009. Reducing Emissions from Deforestation and Forest Degradation (REDD) in Nepal: Exploring the Possibilities. Journal of Forest and Livelihood 8(1) February 2009 
FAO. 2005. Global Forest Resources Assessment. Available http://rainforests.mongabay. com/20nepal.htm accessed in August 10, 2012

FAO. 2003.The state of the world's forests 2003; World statistics table. Food and Agriculture Organization, Rome, Italy.

IPCC. 2007. Fourth Assessment Report - Summary for Policy Makers. Geneva: IPCC. Available at: http://www.ipcc.ch/pdf/assessmentreport/ar4/syr/ar4_syr_spm.pdf accesses in August 10, 2012

Karky, B.S. and Skutch, M. 2010. "The cost of carbon abatement through community forest management in Nepal Himalaya,” Ecological Economics 69(3): 666-672

Karky, S.B., Kotru, R., Rana, E., Karki, S., Poudel, J. 2011. PANEL: Reducing Emissions from Deforestation and Forest Degradation Plus (REDD+): A Spotlight on South Asia Innovative intervention and strategy for implementing REDD+ at community level. International Centre for Integrated Mountain Development (ICIMOD).

Kathmandu, Nepal.

MFSC. 2010. Nepal's Readiness Preparation Proposal REDD 2010-2013. Government of Nepal. Ministry of Forest and Soil Conservation.

MFSC. 2011. Study on REDD Plus Piloting in Nepal. Government of Nepal. REDDForestry and Climate Change Cell, Babarmahal, Kathmandu. June 2011

Parker, C., Mitchell, A., Trivedi, M., Mardas, N., 2009. The Little REDD+ Book: Global Canopy Programme John Krebs Field Station Oxford OX2 8QJ UK.

PSPL \& FECOFUN. 2010. REDD Strategy Option in Nepal Final Draft. Practical Solution Consultancy Nepal Pvt. Ltd (PSPL), Federation of Community Forest Users Nepal (FECOFUN), 2010.

Poudel, K.C., \& Dangi, R. 2011. National Experience with REDD Plus in Nepal.Presentation at Singapore, 15-18 March 2011. 